\title{
MILITARY RECRUITMENT AND CZECH LABOUR MARKET*
}

\author{
Vladan Holcnera (iD, Monika Davidováa (D), Jiří Neubauera iD, \\ Ĺubomír Kubínyia ${ }^{\mathbb{D}}$, Aloiz Flachbart ${ }^{\mathrm{a}}$ (D)
}

\begin{abstract}
The article presents an empirical analysis of the relation between recruitment in the allvolunteer Czech Armed Forces and selected economic indicators, including actual economic performance, situation on the domestic labour market and development of defence expenditures based on data for the period 2005-2019. The relation between military recruitment and economic performance was examined using values of GDP and GDP dynamics (GDP index). General unemployment rate, the economic activity index ${ }^{1}$ and the military-to-general average wage ratio were used to analyse the relation of military recruitment and situation on the domestic labour market. The relation between military recruitment and defence expenditures was examined based on general defence burden (share of defence expenditures in GDP), state sector defence burden (share of defence expenditures in state budget expenditures) and year-on-year changes in defence expenditures.
\end{abstract}

Keywords: Recruitment, military, defence expenditures, labour market, unemployment, gross domestic product

JEL Classification: J20, J40, M50, C40, H50

\section{Introduction}

In the course of the 1990s, the Czech Republic underwent radical social, political, security and economic changes, including the dissolution of the Warsaw Pact in Prague in 1991,

* This research was conducted under the Applied Economics in Defence Department research project within institutional research support at the Faculty of Military Leadership of the University of Defence in Brno.

a University of Defence, Faculty of Military Leadership, Brno, Czech Republic; Emails: vladan.holcner@unob.cz; monika.davidova@unob.cz; jiri.neubauer@unob.cz; lubomir. kubinyi@unob.cz; alojz.flachbart@unob.cz

1 The economic activity index represents an indicator calculated as a share of labour force (employed in national economy and unemployed) and the overall population older than 14 years. 
the splitting of the Czechoslovak federation, a gradual transformation from a centrally planned to an open and market-oriented economy. In 1999, the Czech Republic joined NATO and in 2005, switched from conscription-based to all-volunteer, i.e., a professional armed forces model. As all volunteer forces, the Czech military has to search for, attract, recruit and retain personnel under market conditions on a dynamically evolving labour market. In addition, the Czech defence sector has undergone further major changes, including substantial downsizing, closure of numerous military bases and considerable changes in actual volumes of defence expenditures (Neubauer and Odehnal, 2018).

Since the 1990s, the Czech labour market has been significantly influenced by predominantly favourable domestic economic development, resulting mainly in growing wages and constantly increasing standard of living. Since 2005, the annual general unemployment rate ranged between $7.9 \%$ and $2.0 \%$, representing an average of $5.4 \%$ in 2005-2019 (Czech Statistical Office, 2020). The Czech gross domestic product $(\mathrm{GDP})^{2}$ recorded growth in all but three years of the period 2005-2019 (annually declined only in 2009, 2012 and 2013) (Czech Statistical Office, 2020). The Czech labour market has undergone dynamic changes, on the one hand in terms of levels of wages and their distribution, e.g., based on qualification (Bílková, 2015), on the other hand in terms of labour market flows and unemployment rate dynamics (Flek and Myslíková, 2015). The better economic performance, connected with growing wages and lower unemployment might be connected with the more difficult situation of the all-volunteer armed forces as an employer (Bäckström, 2019).

To better understand relations and dependencies between military recruitment and economic development, an empirical analysis of related data is to be conducted. It is obvious that these relations and dependences may differ from country to country and evolve in time as well.

The aim of this paper is to assess relations between military recruitment and economic development in the Czech Republic between 2005 and 2019. In particular, this paper aims to:

1. analyse relations between military recruitment and economic performance;

2. analyse relations between military recruitment and labour market characteristics;

3. analyse relations between military recruitment and defence expenditure development.

In order to accomplish the aims of this paper, descriptive statistics and correlation analysis were applied, complemented with linear regression models. In particular, the $\mathrm{R}$ Software environment was used to conduct all the calculations presented, enabling statistical computing and graphical processing.

2 Note: GDP data used throughout the paper represent nominal values of GDP as published by the Czech Statistical Office. 


\section{Theory of Military Recruitment}

Authors examining simultaneously selected macroeconomic indicators and characteristics of the defence sector focus mainly on sufficient future human resources capacity in the population. For example, Song and Lee (2019) discuss whether the Korean society will have human resources available to join the Korean military after 2035. They examine how the Korean military maintains the current recruitment system and how it is to evolve in the future. They develop four models that can be regarded as alternative courses of action when managing expected demographic challenges in the Republic of Korea, and examine the credibility of each of the models in terms of demographics and economics.

A different point of view represents a focus on economic studies of military manpower systems and remaining advantages and disadvantages of all-volunteer systems when compared to conscription. Generally, evolving security threats determine the essential need for human resources in a country. However, structural economic variables determine whether the necessary labour can be recruited more effectively through conscription or voluntary military service (Cohn and Toronto, 2017). A similar approach is represented by Bäckström (2019) with an analysis of the relationship between civilian labour market and the supply of labour for the military under conditions of all-volunteer forces in Sweden. He examines the impact of civilian unemployment on the rate of applications in Swedish districts over the period 2011-2015. The results of the panel analysis show that the unemployment rate has a positive and statistically significant effect on the application rate. These results are robust to non-linear specifications and allow for an endogenous civilian unemployment rate. The results suggest that conditions on the Swedish civilian labour market may cause significant fluctuations in recruitment effectiveness in the Swedish Armed Forces. The majority of authors (Ušiak and Görner, 2017) coincidently argue that the higher the demand for military personnel, the less advantageous the all-volunteer model of the armed forces and the concept of conscription becomes more appropriate. On the contrary, some authors state that taxes paid under conditions of all-volunteer forces disturb the economy less (Koch and Birchenall, 2016).

Relations between economic performance and military manpower were examined by Nickelsburg (2020), who analysed the impacts associated with the closure of the US military bases between 1991 and 1999 after the end of the Cold War. He presents a natural experiment providing evidence of the impact of defence spending cycles on the labour market. The results of his experiment are in line with the search for declining wage rigidities in the sector, increasing adjustment costs; nevertheless, they are generally not in line with theories of market interventions in long-term unemployment. Asch et al. (2010) analysed remuneration in the US Army and Navy using the fiscal years 2000-2008, deriving a conclusion that for the Army an optimum pay differential represents a relation of relevant military and civilian pay at the level of $115 \%$. This means that if the level 
of military pay were to rise by $10 \%$ relative to civilian wage opportunities, enlistment of adequately qualified youth would rise by $11.5 \%$.

Similarly to the case of recruitment, imbalance in retention of military personnel might cause problems in personnel management connected with deceasing effectiveness of military activities, indicated e.g., by lack of experienced commanders (Kapp, 2013).

As personnel outlays represent more than half the Czech defence expenditures, the link between military recruitment, defence expenditures and their determinants is another area of interest (Gadea et al., 2004). Warner argues that military recruitment and retention respond to wages in the civilian sector. By estimation, when wages in the civilian sector remain unchanged, enhancement of present as well as future military compensation by $10 \%$ is to result in an increase in interest of highly qualified recruits by $6 \%$ to $11 \%$ (Warner, 2012). The actual level of defence expenditures depends on a number of economic, political and security determinants. Especially budget balance, inflation, GDP values, GDP dynamics and others have been included among the economic determinants. However, previous research indicates inconsistencies in their influence on actual levels of defence spending on the international scale (Odehnal and Neubauer, 2020). Is there any relation between defence expenditures and their selected determents on the one hand and recruitment to the Czech Armed Forces on the other hand?

\section{Analysis of Influence of Economic Development on Military Recruitment}

As mentioned above, besides a respective nation's defence policy, military recruitment is dependent mainly on development of various economic parameters. Only limited analyses of the linkage between economic development and military recruitment are available worldwide. No studies have been published yet on this topic for the Czech economy and the Czech Armed Forces. What is the connection between the development of key economic variables, situation on the national labour market and national defence sector funding on the one hand and military recruitment in the Czech Armed Forces on the other hand? This chapter presents analyses indicating answers to this question based on data between the years 2005 and 2019.

\subsection{Hypotheses and methods of their verification}

Generally, we can expect that better economic conditions (GDP, including its dynamics) make recruitment, i.e., also military recruitment, more difficult (Vavrek et al., 2015). On the contrary, economic decline creates favourable conditions for successful military recruitment. As to the labour market, we can anticipate that higher unemployment will result in higher number of newly recruited soldiers or similarly, that a higher economic 
activity index will impede military recruitment (Bäckström, 2019). Another labour market factor, which expectedly influences military recruitment, is the ratio of average wage of military personnel to average wage in the economy (military pay differential). The higher this ratio, the better conditions for military recruitment can be expected (Warner et al., 2003). Under conditions of booming information technologies and related autonomous and robotic systems, the relatively higher costs of military manpower can be mitigated to a certain extent by substituting military manpower with robots (Olejníček et al., 2018). ${ }^{3}$ Finally, we expect that military recruitment is influenced by defence expenditures, namely their share in the GDP, their share in government expenditures and their dynamics.

To examine the validity of these expectations, correlations between the number of newly recruited military personnel and the following economic characteristics were considered, and the following sources of data were used:

- GDP (Czech Statistical Office, 2020),

- year-on-year (YOY) GDP index (Czech Statistical Office, 2020),

- general unemployment rate (Czech Statistical Office, 2020), ${ }^{4}$

- $\quad$ economic activity index (Czech Statistical Office, 2020),

- military personnel average wage to general average wage ratio (Ministry of Defence of the Czech Republic, 2020; Ministry of Finance of the Czech Republic, 2020),

- $\quad$ share of defence expenditures in GDP (Ministry of Defence of the Czech Republic, 2020),

- $\quad$ share of defence expenditures in state budget expenditures (Ministry of Defence of the Czech Republic, 2020),

- $\quad$ YOY defence expenditures index (Ministry of Defence of the Czech Republic, 2020). ${ }^{5}$

3 Note: The idea of substitution of labour with capital (military manpower with military robots) is not taken into further consideration in the present research. The scope of autonomous and robotic systems introduced in the Czech military indicates that any potential significant effect of this phenomenon is still to be expected in the future.

4 Note: This research does not consider structural differences between professional military personnel and general labour force or unemployed persons on the Czech labour market. However, these differences are obvious. For example, as of 1 January 2020, professional military personnel in the Czech Armed Forces consisted of $13 \%$ women and $87 \%$ men, compared to the nearly even gender structure of the Czech labour force and to the prevalence of women among the unemployed (the 2019 unemployment rate was $2 \%$, which represented $2.4 \%$ unemployment rate for women and just $1.7 \%$ for men). Similar differences between the Czech military labour and the unemployed on the Czech labour market relate to the level of education and age. While in the Czech military, $30.2 \%$ of persons are university graduates, just $1 \%$ of university graduates are unemployed in the Czech Republic. More than $35 \%$ of the unemployed are older than 44 years; this age group represents just approx. $23 \%$ of the Czech military personnel (Czech Statistical Office, 2020; Ministry of Defence of the Czech Republic, 2020).

5 For the purpose of the calculations, especially when creating the regression model, a supplementary variable was used, indicating the number of inhabitants in the Czech Republic (Czech Statistical Office, 2020). 
With this regard, eight hypotheses were formulated, reflecting the potential link between military recruitment in the Czech Armed Forces and the Czech economic development:

$H_{1}$ : Higher GDP impedes military recruitment and results in lower numbers of newly recruited military personnel.

$H_{2}$ : YOY increase in GDP impedes military recruitment and results in lower numbers of newly recruited military personnel.

$H_{3}$ : Higher unemployment rate has a positive influence on military recruitment and results in higher numbers of newly recruited military personnel.

$H_{4}$ : Higher economic activity index has a negative influence on military recruitment and results in lower numbers of newly recruited military personnel.

$H_{5}$ : Higher ratio of military personnel average wage to general average wage has a positive influence on military recruitment and results in higher numbers of newly recruited military personnel.

$H_{6}$ : Higher share of defence expenditures in GDP has a positive influence on military recruitment and results in higher numbers of newly recruited military personnel.

$H_{7}$ : Higher share of defence expenditures in total state budget expenditures has a positive influence on military recruitment and results in higher numbers of newly recruited military personnel.

$H_{8}$ : YOY increase in defence expenditures has a positive influence on military recruitment and results in higher numbers of newly recruited military personnel.

The hypotheses outlined above were verified using official data published by re- spective official authorities of the Czech Republic. First, to examine the validity of these hypotheses, i.e., relations between military recruitment and selected economic characteristics, the measure of association of each of these examined pairs of variables was characterized by the Pearson correlation coefficient, where statistical significance of the correlation was tested. Subsequently, a linear regression model with the number of recruited military personnel as the dependent variable was created to verify results of the previous correlation analysis (Devore, 2012).

\subsection{Statistical evaluation of anticipated relationships: empirical results}

To describe the results of the survey and verify relations between military recruitment described as the number of newly recruited military personnel and individual economic characteristics, this subchapter presents a series of results of respective correlation analyses, divided into three areas of interest: 
- military recruitment and overall economic development,

- military recruitment and labour market characteristics, and

- military recruitment and defence expenditures.

The correlation analyses were supplemented with regression modelling used as a tool verifying results of the correlation analyses. Table 1 presents an overview of data used for the correlation analyses.

\subsubsection{Correlation analysis of relation between number of recruited military personnel and selected economic characteristics}

First, the relation between the number of recruited military personnel and economic performance, i.e., GDP, and YOY GDP index (see Table 1) is presented. The analysis of the relation between the number of recruited military personnel and GDP did not prove any statistically significant correlation at the 0.10 significance level (see Figure 1 and Table 2).

Therefore, hypothesis $\boldsymbol{H}_{\mathbf{1}}$ has not been confirmed, i.e., the development in the Czech Republic between 2005 and 2019 shows that better economic performance (higher GDP) was not connected with impeded military recruitment (lower numbers of newly recruited military personnel). On the other hand, YOY increases of GDP occurred in the same years when the Czech Armed Forces recruited higher numbers of recruited military personnel (see Figure 1 and Table 2). Correlation of these parameters was confirmed statistically at the 0.05 significance level; here the correlation coefficient is 0.520 with a $p$-value of 0.04674 . Therefore, the 2005-2019 data disprove hypothesis $\boldsymbol{H}_{2}$.

As to the relation between military recruitment and economic performance, the analysis proved no statistically significant connection between the development of the number of personnel recruited in the Czech military and GDP. Contrary to general expectations, years characterized by YOY increases of GDP were connected with higher numbers of recruited military personnel. 
Table 1: Number of military personnel recruited in Czech Armed Forces and selected economic characteristics, 2005-20196

\begin{tabular}{|c|c|c|c|c|c|}
\hline Year & $\begin{array}{l}\text { Recruited } \\
\text { military } \\
\text { personnel }\end{array}$ & $\begin{array}{c}\text { GDP } \\
\text { (CZK mil.) }\end{array}$ & $\begin{array}{l}\text { YOY GDP } \\
\text { index } \\
(\%)\end{array}$ & $\begin{array}{l}\text { Unemployment } \\
\text { rate } \\
(\%)\end{array}$ & $\begin{array}{c}\text { Economic } \\
\text { activity index } \\
(\%)\end{array}$ \\
\hline 2005 & 2,068 & $3,264,931$ & 106.5 & 7.9 & 59.4 \\
\hline 2006 & 2,233 & $3,512,798$ & 106.9 & 7.1 & 59.3 \\
\hline 2007 & 1,219 & $3,840,117$ & 105.6 & 5.3 & 58.8 \\
\hline 2008 & 1,149 & $4,024,117$ & 102.7 & 4.4 & 58.5 \\
\hline 2009 & 1,159 & $3,930,409$ & 95.2 & 6.7 & 58.7 \\
\hline 2010 & 380 & $3,962,464$ & 102.3 & 7.3 & 58.4 \\
\hline 2011 & 569 & $4,033,755$ & 101.8 & 6.7 & 58.3 \\
\hline 2012 & 949 & $4,059,912$ & 99.2 & 7.0 & 58.6 \\
\hline 2013 & 574 & $4,098,128$ & 99.5 & 7.0 & 59.3 \\
\hline 2014 & 633 & $4,313,789$ & 102.7 & 6.1 & 59.3 \\
\hline 2015 & 1,851 & $4,595,783$ & 105.3 & 5.0 & 59.4 \\
\hline 2016 & 2,147 & $4,767,990$ & 102.5 & 4.0 & 59.9 \\
\hline 2017 & 2,173 & $5,047,267$ & 104.4 & 2.9 & 60.2 \\
\hline 2018 & 1,977 & $5,323,556$ & 102.8 & 2.2 & 60.6 \\
\hline 2019 & 1,892 & $5,652,553$ & 102.6 & 2.0 & 60.4 \\
\hline Year & $\begin{array}{c}\text { Military-to- } \\
\text { general average } \\
\text { wage ratio (\%) }\end{array}$ & $\begin{array}{c}\text { Share } \\
\text { of defence } \\
\text { expenditures } \\
\text { in GDP (\%) }\end{array}$ & $\begin{array}{c}\text { Defence } \\
\text { expenditures } \\
\text { to state budget } \\
\text { expenditures (\%) }\end{array}$ & $\begin{array}{l}\text { YOY defence } \\
\text { expenditure } \\
\text { index }(\%)\end{array}$ & Population \\
\hline 2005 & 129.0 & 2.00 & 6.34 & 100.00 & $10,251,079$ \\
\hline 2006 & 118.6 & 1.96 & 6.18 & 107.97 & $10,287,189$ \\
\hline 2007 & 118.0 & 1.74 & 5.62 & 97.20 & $10,381,130$ \\
\hline 2008 & 116.1 & 1.44 & 4.78 & 86.24 & $10,467,542$ \\
\hline 2009 & 111.9 & 1.65 & 5.12 & 112.91 & $10,506,813$ \\
\hline 2010 & 110.1 & 1.38 & 4.40 & 85.13 & $10,532,770$ \\
\hline 2011 & 101.9 & 1.23 & 3.96 & 89.90 & $10,505,445$ \\
\hline 2012 & 97.4 & 1.13 & 3.73 & 93.93 & $10,516,125$ \\
\hline 2013 & 97.9 & 1.08 & 3.54 & 96.57 & $10,512,419$ \\
\hline 2014 & 102.3 & 0.96 & 3.39 & 99.05 & $10,538,275$ \\
\hline 2015 & 106.9 & 1.06 & 3.65 & 115.27 & $10,553,843$ \\
\hline 2016 & 112.4 & 0.97 & 3.74 & 96.34 & $10,578,820$ \\
\hline 2017 & 113.4 & 1.05 & 4.04 & 116.01 & $10,610,055$ \\
\hline 2018 & 119.5 & 1.13 & 4.27 & 113.02 & $10,649,800$ \\
\hline 2019 & 117.5 & 1.20 & 4.43 & 111.60 & $10,693,939$ \\
\hline
\end{tabular}

Source: Ministry of Defence of the Czech Republic (2020), Czech Statistical Office (2020; 2020), own calculation

$6 \quad$ Note: For YOY GDP Index and YOY defence expenditure index previous year $=100$. 
Table 2: Correlation between number of recruited military personnel and selected economic characteristics, 2005-2019

\begin{tabular}{l|c|c}
\hline Selected economic characteristics & $\begin{array}{c}\text { Correlation } \\
\text { coefficient }\end{array}$ & $\boldsymbol{p}$-value \\
\hline GDP & 0.325 & 0.23760 \\
\hline YOY GDP index & 0.520 & 0.04674 \\
\hline General unemployment rate & -0.496 & 0.06034 \\
\hline Economic activity index & 0.714 & 0.00278 \\
\hline Military personnel average wage to general average wage ratio & 0.670 & 0.00630 \\
\hline Share of military expenditures in GDP & 0.186 & 0.50600 \\
\hline Share of military expenditures in state budget expenditures & 0.366 & 0.17960 \\
\hline YOY defence expenditures index & 0.565 & 0.02808 \\
\hline
\end{tabular}

Source: Own calculation

The relation between military recruitment and the situation on the Czech labour market was examined using correlation between the number of recruited personnel and general unemployment rate, economic activity index and the ratio of military personnel average wage to the general average wage, i.e., the military-civilian pay differential (see Table 1).

Surprisingly, the relation between the number of recruited military personnel and general unemployment rate can be characterized as an inverse proportion. With a higher unemployment rate, lower numbers of military personnel have been recruited to the Czech military. This correlation was confirmed statistically at the 0.10 significance level with a correlation coefficient of -0.496 and a $p$-value of 0.06034 (see Figure 1 and Table 2). Therefore, hypothesis $\boldsymbol{H}_{3}$ has been disproved.

Similarly to the case of the relation between the number of recruited military personnel and general unemployment rate, the relation between the number of recruited military personnel and economic activity index development can be characterized as unanticipated. The higher the economic activity recorded on the labour market, the lower the numbers of personnel recruited to the Czech military. The positive correlation of these two parameters is characterized at the 0.05 statistical significance level by a correlation coefficient of 0.714 and a $p$-value of 0.00278 (see Figure 1 and Table 2). Thus, hypothesis $\boldsymbol{H}_{4}$ has been disproved as well. 
Figure 1: Relation between number of recruited military personnel and selected economic characteristics
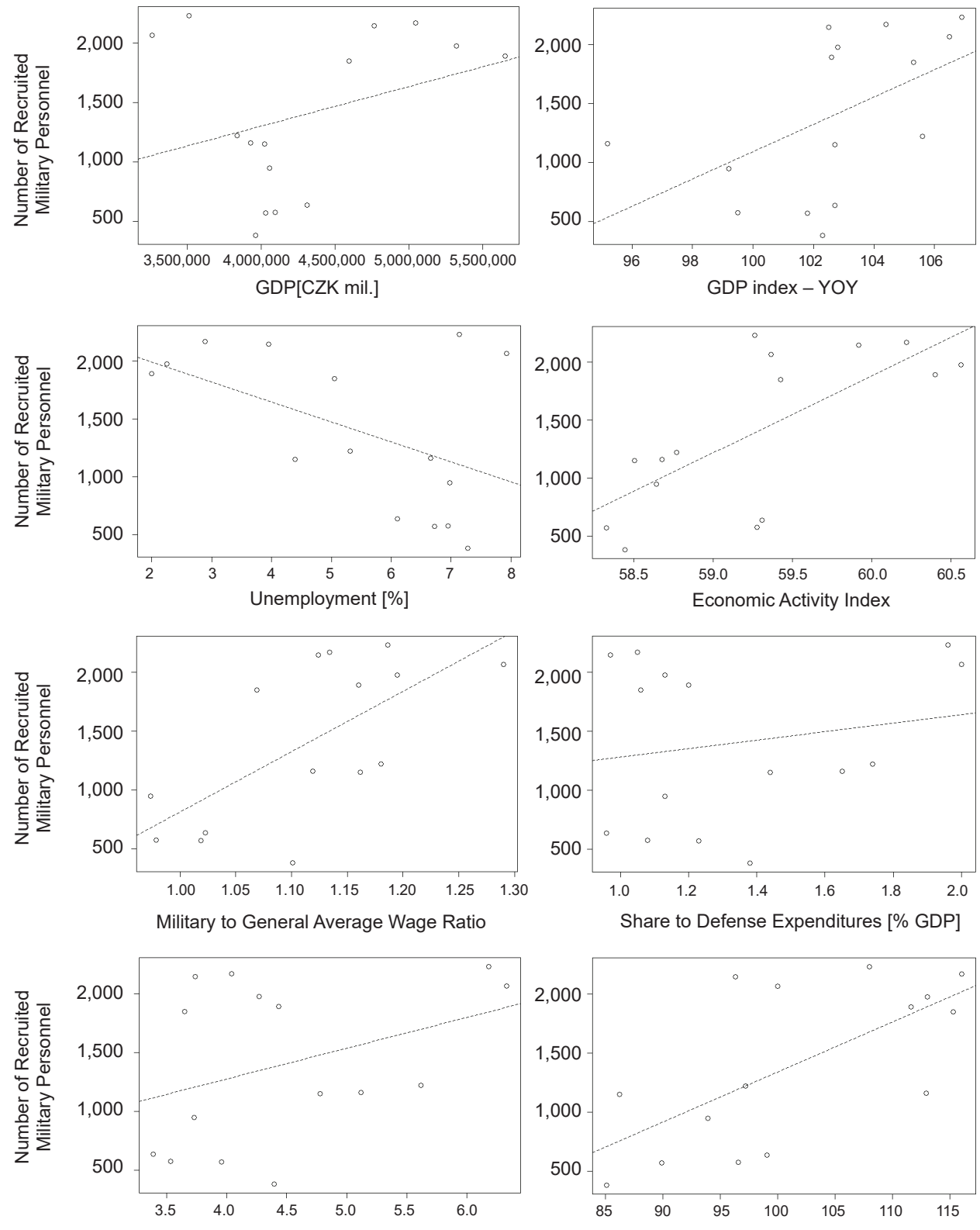

Military Expenditures [\% State Budget Expenditures]

Defense Expenditures - YOY

Source: Own calculation 
The third of the characteristics analysed in the context of the labour market was the ratio of the average wage of military personnel and the average wage in the Czech economy. The analysis of the relation of this parameter to the number of recruited personnel proved a positive correlation at the 0.05 level of significance with a correlation coefficient of 0.670 and a $p$-value of 0.00630 (see Figure 1 and Table 2). As expected, the higher the positive difference between the wage in the military and in general economy, the more recruits attracted to the Czech military. Therefore, we can consider hypothesis $\boldsymbol{H}_{5}$ to be confirmed.

The relation of military recruitment and the actual situation on the labour market proved to be rather different from initial expectations. A lower unemployment rate and a higher economic activity index was connected with higher numbers of recruited military personnel. As expected, better remuneration in the military in relation to the general situation on the labour market was connected with higher numbers of recruited military personnel.

The relation between the military recruitment and development of the Czech defence expenditures was examined using three indicators - two representing defence burden in the Czech economy or the Czech public sector and one expressing dynamics of the Czech defence expenditure development (see Table 1).

The analysis of the relation between the number of recruited military personnel and defence burden expressed as a share of defence expenditures in GDP did not prove any statistically significant correlation (a correlation coefficient of 0.186 and a $p$-value of 0.50600 ; see Figure 1 and Table 2). Thus, hypothesis $\boldsymbol{H}_{6}$ has not been confirmed.

The development of the Czech state sector defence burden, expressed as a share of defence expenditures in state budget expenditures, correlates with the number of recruited military personnel; however, this correlation proves to be statistically insignificant (correlation coefficient $0.366, p$-value 0.17960 ). Thus, hypothesis $\boldsymbol{H}_{7}$ has not been confirmed. Figure 1 shows the relation of the development of these two parameters (see also Table 2).

Unlike the defence burden development, the YOY changes in defence expenditures proved to strongly correlate with the number of recruited military personnel. Correlation of these parameters was proven at the 0.05 significance level with a correlation coefficient of 0.565 and a $p$-value of 0.02808 (see Figure 1 and Table 2), confirming hypothesis $\boldsymbol{H}_{\mathbf{8}}$.

The results of the correlation analyses indicate that the Czech defence expenditure development between 2005 and 2019 was influential concerning military recruitment only in terms of their share in the overall state budget expenditures (but here, the correlation detected proved to be rather statistically insignificant) and in terms of their dynamics. The analysis results show no statistically significant relation between the development of military recruitment and the Czech defence burden. 


\subsubsection{Number of recruited military personnel and selected economic characteristics: linear regression model}

Linear regression models were designed to verify the results of the correlation analysis. When creating the linear regression models, it was deemed appropriate to include a variable indicating the number of inhabitants in the Czech Republic. The following variables were used in the model:

- $\quad$ number of recruited military personnel (NRMP),

- $\quad$ population, in millions of inhabitants $(P O P)$,

- gross domestic product, in billions of CZK $(G D P)$,

- YOY gross domestic product index, in \% (GDP.IND),

- general unemployment rate, in \% (UNEMPL),

- $\quad$ economic activity index, in \% (EAI),

- military personnel average wage to general average wage ratio, in \% (WAGE.RATIO),

- $\quad$ share of military expenditures in GDP, in \% (MILEX.GDP),

- $\quad$ share of military expenditures in state budget expenditures, in \% (MILEX.BUDGET),

- YOY defence expenditures index, in \% (MILEX.IND).

The estimated model parameters containing all the selected economic characteristics (full model) proved to be statistically insignificant. For this reason, it was deemed appropriate to proceed with a reduction of variables included in the model. The final model was constructed using the stepwise regression method (the backward selection method); see Table 3 .

$N R M P=25477,27+6417,17$ WAGE.RATIO - 1554,45MILEX.GD + 35,47MILEX.IND

The analysis of residuals of the estimated model did not reveal any violation of the assumptions of the linear regression model. Normality was tested using the Shapiro-Wilk, Anderson-Darling and Lilliefors tests (the $p$-values are $0.2309,0.1163$ and 0.1681 ). The Durbin-Watson test was applied as the autocorrelation test ( $p$-value being 0.3319). Therefore, the residuals of the model can be considered normally distributed and uncorrelated.

The resulting (final) linear regression model contains only three economic characteristics. Its results indicate that the higher the ratio of the military personnel average wage to the general average wage, the higher the number of personnel recruited in the Czech military. This conclusion corresponds with the results acquired using the correlation coefficient (hypothesis $\boldsymbol{H}_{5}$ confirmed).

The negative figures in the coefficient estimates of the variable MILEX.GDP indicate that the higher the share of military expenditures in GDP, the lower the numbers 
of personnel newly recruited in the Czech military. Although the correlation coefficient between the share of military expenditures in GDP and the number of recruited military personnel is positive, it is statistically insignificant. This finding corresponds with the results of the previous correlation analysis; that is, results of the reduced regression model do not confirm hypothesis $\boldsymbol{H}_{6}$.

With regard to the influence of YOY changes in defence expenditures, expressed by the YOY defence expenditures index, on military recruitment, we can state that YOY increases in defence expenditures are connected with higher numbers of recruited military personnel. This finding supports the results of the correlation analysis as well (hypothesis $H_{8}$ confirmed).

Table 3: Linear regression models

\begin{tabular}{|c|c|c|}
\hline Variables & $\begin{array}{l}\text { Full model } \\
\text { estimates }\end{array}$ & $\begin{array}{c}\text { Final model } \\
\text { estimates }\end{array}$ \\
\hline const. & $\begin{array}{c}147,841.85 \\
(130,382.60)\end{array}$ & $\begin{array}{c}25,477.27 \\
(17,425.52)\end{array}$ \\
\hline POP & $\begin{array}{c}-11,229.28 \\
(9558.36)\end{array}$ & $\begin{array}{l}-3117.88 * \\
(1666.58)\end{array}$ \\
\hline GDP & $\begin{array}{c}2.08 \\
(2.26)\end{array}$ & $\begin{array}{l}- \\
-\end{array}$ \\
\hline GDP.IND & $\begin{array}{l}-62.85 \\
(81.80)\end{array}$ & $\begin{array}{l}- \\
-\end{array}$ \\
\hline UNEMPL & $\begin{array}{c}270.22 \\
(314.45)\end{array}$ & $\begin{array}{l}- \\
-\end{array}$ \\
\hline EAI & $\begin{array}{c}-684.34 \\
(772.01)\end{array}$ & $\begin{array}{l}- \\
-\end{array}$ \\
\hline WAGE.RATIO & $\begin{array}{c}4168.05 \\
(5026.93)\end{array}$ & $\begin{array}{l}6417.17^{* * *} \\
(1611.32)\end{array}$ \\
\hline MILEX.GDP & $\begin{array}{r}-8440.61 \\
(6424.15)\end{array}$ & $\begin{array}{c}-1554.45 * * \\
(676.40)\end{array}$ \\
\hline MILEX.BUDGET & $\begin{array}{c}2515.73 \\
(2368.35)\end{array}$ & $\begin{array}{l}- \\
-\end{array}$ \\
\hline MILEX.IND & $\begin{array}{c}34.48 \\
(17.70)\end{array}$ & $\begin{array}{l}35.47^{* * *} \\
(10.17)\end{array}$ \\
\hline$R^{2}$ & 0.885 & 0.806 \\
\hline$R_{\text {adj }}^{2}$ & 0.679 & 0.728 \\
\hline
\end{tabular}

Note: Number of recruited military personnel as dependent variable; standard deviations in parentheses; ${ }^{*}$ statistically significant at $0.10,{ }^{* *}$ at $0.05,{ }^{* * *}$ at 0.01 . Source: Own calculation 


\section{Conclusion}

The presented correlation analyses enabled us to confirm two out of the eight formulated hypotheses. Four additional hypotheses were disproved and two were not confirmed. Thus, the results of the correlation analyses indicate that the number of newly recruited military personnel grows with a higher ratio of the average military personnel wage to the general average wage and with annual increases in military expenditures. Similarly, based on the correlation analysis results, we can state that recruitment to the Czech military has not been impeded by YOY increase in GDP, lower unemployment or higher economic activity index.

Table 4: Overview of hypotheses and results of their verification

\begin{tabular}{l|l|l}
\hline Hypothesis & $\begin{array}{c}\text { Correlation } \\
\text { analysis result }\end{array}$ & $\begin{array}{c}\text { Linear regression } \\
\text { result }\end{array}$ \\
\hline $\begin{array}{l}H_{1}: \text { Higher GDP impedes military recruitment and results } \\
\text { in lower numbers of newly recruited military personnel. }\end{array}$ & Not confirmed. & Not confirmed. \\
\hline $\begin{array}{l}H_{5}: \text { YOY increase in GDP impedes military recruitment } \\
\text { and results in lower numbers of newly recruited military } \\
\text { personnel. }\end{array}$ & Disproved. & Not confirmed. \\
\hline $\begin{array}{l}H_{3}: \text { Higher unemployment rate has a positive influence } \\
\text { on military recruitment and results in higher numbers } \\
\text { of newly recruited military personnel. }\end{array}$ & Disproved. & Not confirmed. \\
\hline $\begin{array}{l}H_{4}: \text { Higher economic activity index has a negative influence } \\
\text { on military recruitment and results in lower numbers } \\
\text { of newly recruited military personnel. }\end{array}$ & Disproved. & Not confirmed. \\
\hline $\begin{array}{l}H_{5}: \text { Higher ratio of military personnel average wage } \\
\text { to general average wage has a positive influence on military } \\
\text { recruitment and results in higher numbers of newly recruited } \\
\text { military personnel. }\end{array}$ & Confirmed. & Confirmed. \\
\hline $\begin{array}{l}H_{6}: \text { Higher share of Military Expenditures in GDP has } \\
\text { a positive influence on military recruitment and results } \\
\text { in higher numbers of newly recruited military personnel. }\end{array}$ & Not confirmed. & Not confirmed. \\
\hline $\begin{array}{l}H_{5}: \text { Higher share of Military Expenditures in total state } \\
\text { budget expenditures has a positive influence on military } \\
\text { recruitment and results in higher numbers of newly recruited } \\
\text { military personnel. }\end{array}$ & Not confirmed. & Not confirmed. \\
\hline $\begin{array}{l}H_{5}: \text { Annual increase in military expenditures has a positive } \\
\text { influence on military recruitment and results in higher } \\
\text { numbers of newly recruited military personnel. }\end{array}$ & Confirmed. & Confirmed. \\
\hline
\end{tabular}

Source: Own 
However, the results of the linear regression models confirmed the correlation analysis results only partially. As to the connection between military recruitment and economic performance, neither of the two hypotheses was confirmed. With regard to the connection between military recruitment and the labour market, one hypothesis was confirmed and two hypotheses were not confirmed. And finally, in terms of the relation of military recruitment and defence expenditures, one hypothesis was confirmed and the two remaining were not confirmed (see Table 4).

It means that the reduced linear regression model results correspond with the results of the correlation analyses in the case of five out of eight hypotheses. However, a combination of these two methods enabled us to prove the validity of only two of these hypotheses, i.e., the relation of two economic characteristics (military personnel average wage to general average wage ratio and defence expenditure dynamics) and military recruitment in the Czech Armed Forces.

Thus, based on the two sets of analyses of the relation between recruitment of military personnel in the all-voluntary Czech Armed Forces and selected economic indicators, we can derive the following conclusions. First, a negative influence of higher economic performance, expressed as GDP values or their dynamics, on the number of personnel recruited in the Czech military, was not confirmed. Furthermore, a positive influence of higher unemployment rate, lower economic activity index, higher share of military expenditures in GDP or higher share of military expenditures in total state budget expenditures on the number of personnel recruited in the Czech military was not confirmed either. On the contrary and as expected, we can conclude that between 1999 and 2005, higher numbers of recruited military personnel in the Czech Republic were connected with a higher military-civil pay differential and YOY increases in Czech defence expenditures.

\section{References}

Asch, B., Heaton, P., Hosek, J., et al. (2010). Cash Incentives and Military Enlistment, Attrition, and Reenlistment. Santa Monica, California: RAND Corporation. ISBN 9780833049667.

Bäckström, P. (2019). Are Economic Upturns Bad for Military Recruitment? A Study on Swedish Regional Data 2011-2015. Defence and Peace Economics, 30(7), 813-829, http://doi.org/1 $0.1080 / 10242694.2018 .1522572$

Bílková, D. (2015). Financial Position of Czech Employees at the Beginning of the $3^{\text {rd }}$ Millennium According to Educational Attainment. Prague Economic Papers, 24(3), 307-331, http://doi.org/10.18267/j.pep.521

Cohn, L. P., Toronto, N. W. (2017). Markets and Manpower: The Political Economy of Compulsory Military Service. Armed Forces \& Society, 43(3), 436-458, http://doi.org/ $10.1177 / 0095327 \times 16667086$ 
Czech Statistical Office (2020). General Unemployment Rate by Cohesion Regions and Regions-Annual Average. Prague: Czech Statistical Office [Retrieved 2020-04-11]. Available at: https://vdb.czso.cz/vdbvo2/faces/en/index.jsf?page=vystupobjekt\&z=T\&f=TABULKA\&filtr=G\%7EF_M\%7EF_Z\%7EF_R\%7ET_P\%7E_S \%7E_null_null_\&katalog=30853\&pvo=ZAM06\&str=v95\&c=v147 8_RP2017\#w=

Czech Statistical Office (2020). Gross Domestic Product of the Czech Republic by the Expenditure Approach. Prague: Czech Statistical Office [Retrieved 2020-04-03] Available at: https://vdb.czso.cz/vdbvo2/faces/cs/index.jsf?page=vystup-objekt\&z=T\&f=TABULKA\&sk upld=486\&katalog=30832\&pvo=NUC02-S1 az3\&pvo=NUC02-S1 az3\&str=v64\#w=

Czech Statistical Office (2020). Public Database. Age, Education and Specific Groups of Unemployed. Prague: Czech Statistical Office [Retrieved 2021-02-14] Available at: https://vdb.czso.cz/vdbvo2/faces/en/index.jsf?page=vystup-objekt\&pvo=ZAM08$A \& z=T \& f=T A B U L K A \&$ skupld=748\&filtr=G\%7EF_M\%7EF_Z\%7EF_R\%7ET_P\%7E_S \%7E_null_null_\&katalog=30853\&pvo=ZAM08-A\&str=v221\&c=v3 8_RP2019

Devore, J. L. (2012). Probability and Statistics for Engineering and the Science. $8^{\text {th }}$ ed. Brooks/ Cole, Cengage Learning. ISBN 978-0-8400-6827-9.

Flek, V., Myslíková, M. (2015). Uneployment Dynamics in Central Europe: A Labour Flow Approach. Prague Economic Papers, 24(1), 73-87, http://doi.org/10.18267/j.pep.501

Gadea, M. D., Pardos, E., Pérez-Forniés, C. (2004). A Long-Run Analysis of Defence Spending in the NATO Countries (1960-99). Defence and Peace Economics, 15(3), 231-249, https://doi.org/10.1080/1024269042000189273

Kapp, L. (2015). Recruiting and Retention: An Overview of FY2013 and FY2014 Results for Active and Reserve Component Enlisted Personnel. Congressional Research Service [Retrieved 2020-07-02] Available at: https://crsreports.congress.gov/product/pdf/RL/RL32965

Koch, T., Birchenall, J. (2016). Taking Versus Taxing: An Analysis of Conscription in a Private Information Economy. Public Choice, 167(3-4), 177-199, https://doi.org/10.1007/ s11127-016-0334-7

Ministry of Defence of the Czech Republic (2018). Defence Budget. Basic Data of the State Budget in Chapter of the Ministry of Defence in 1993-2018. Prague: MoD [Retrieved 2020-06-05] Available at: http://www.army.cz/en/facts-file/defence-budget/ defence-budget-130198/

Ministry of Defence of the Czech Republic (2020). Financial Information System-Information System of Service and Personnel-Statistics. Prague: MoD.

Ministry of Defence of the Czech Republic. Czech Armed Forces Personnel Agency (2006-2020). Statistical Yearbooks 2006-2020. Prague: MoD.

Ministry of Finance of the Czech Republic (2020). Budgetary Frameworks-Statistical Information. Prague: MoD [Retrieved 2020-06-23] Available at: https://www.mfcr.cz/en/ statistics/budgetary-frameworks-statistical-information 
Neubauer, J., Odehnal, J. (2018). Security and Economic Determinants of the Demand for Czech Military Expenditure: ARDL Approach. International Conference of Numerical Analysis and Applied Mathematics (ICNAAM 2017) AIP Conf. Proc. 1978. Melville: AIP Publishing, https://doi.org/10.1063/1.5043741

Nickelsburg, J. (2020). Employment Dynamics in Local Labor Markets: Evidence from US Post Cold War Base Closures. Defence and Peace Economics, 31(8), 990-1005, https://doi.org/10.1080/10242694.2019.1600785

Odehnal, J., Neubauer, J. (2020). Economic, Security, and Political Determinants of Military Spending in NATO Countries. Defence and Peace Economics, 31(5), 517-531, http://doi.org/10.1080/10242694.2018.1544440

Olejníček, A., Odehnal, J., Holcner, V., et al. (2018) Determinants of Military Robotics Proliferation. Advances in Military Technology, 13(1), 71-86, https://doi.org/10.3849/ aimt.01218

Song, Y. S., Lee, W. (2019). The Study on the Innovation of the Recruitment Policy of the Future Military Preparing for the Upcoming Demographic Cliff in South Korea - the Alternative Approach of Hybrid Military Service System. Journal of Policy Development, 19(2), 1-39.

Ušiak, J., Görner, E. (2017). Economic Theories of Military Recruitment. In: International Relations 2017: Current Issues of World Economy and Politics. Proceedings of the $18^{\text {th }}$ International Scientific Conference. Smolenice: Ekonóm, pp. 1023-1033.

Vavrek, R., Juskova, M., Bednarova, L. (2016). Correlations between Selected Macroeconomic Indicators - Case Study of Slovak Republic and Czech Republic. In: $3^{\text {rd }}$ International Multidisciplinary Scientific Conference on Social Sciences \& Arts. Albena, pp. 793-798.

Warner, J. T. (2012). The Effect of the Civilian Economy on Recruiting and Retention. In: Report of the Eleventh Quadrennial Review of Military Compensation. Supporting Research Papers. Washington, DC: US Department of Defense, pp. 71-91. https://militarypay.defense.gov/Portals/3/Documents/Reports/11th_QRMC_ Supporting_Research_Papers_(932pp)_Linked.pdf

Warner, J. T., Simon, C. J., Payne, D. M. (2003). The Military Recruiting Productivity Slowdown: The Roles of Resources, Opportunity Cost and the Tastes of Youth. Defence and Peace Economics, 14(5), 329-342, https://doi.org/10.1080/10242690302923 